BMC

Microbiology

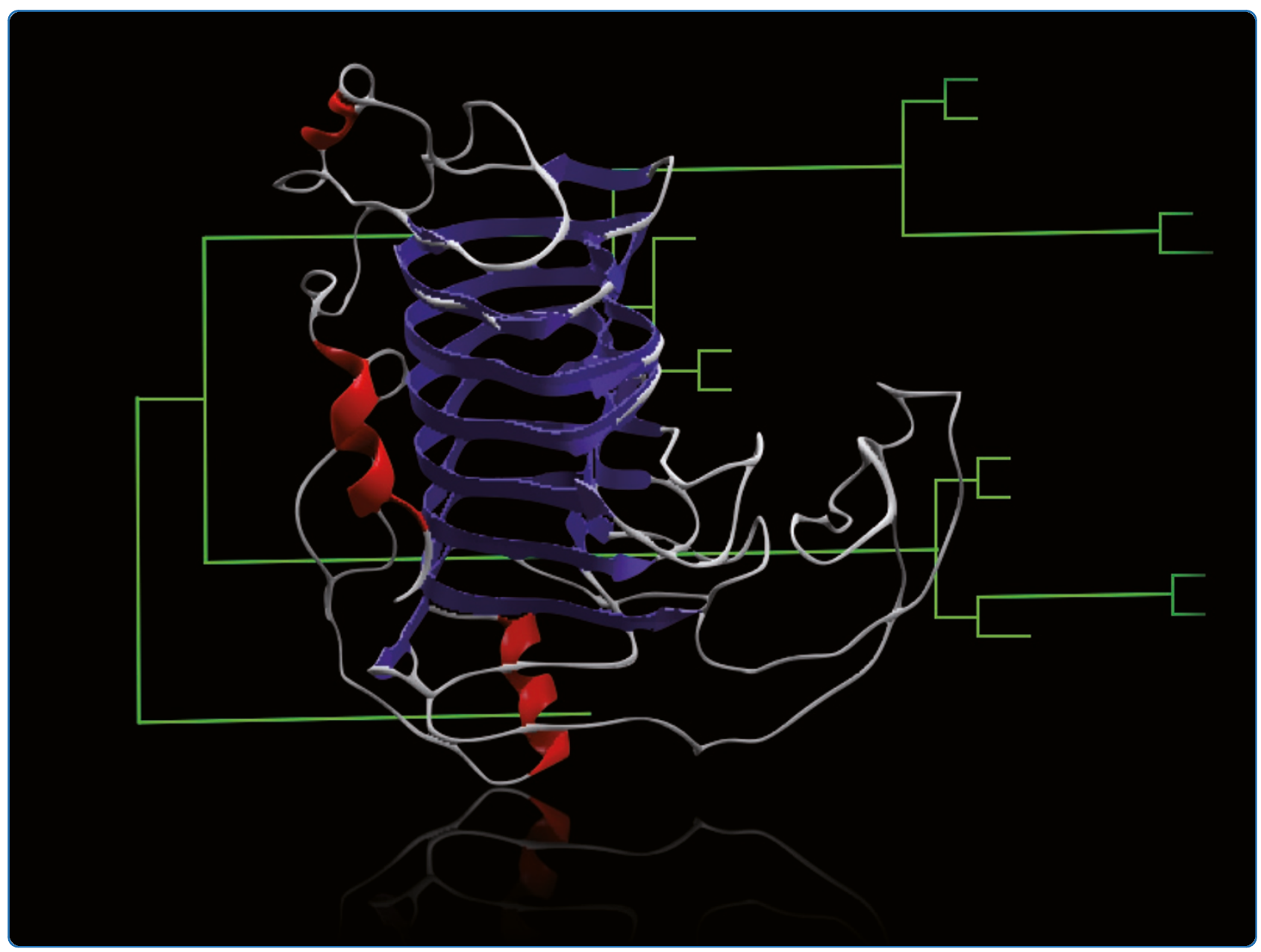

Cloning and characterization of a pectin lyase gene from Colletotrichum lindemuthianum and comparative phylogenetic/structural analyses with genes from phytopathogenic and saprophytic/opportunistic microorganisms

Lara-Márquez et al. 


\title{
Cloning and characterization of a pectin lyase gene from Colletotrichum lindemuthianum and comparative phylogenetic/structural analyses with genes from phytopathogenic and saprophytic/opportunistic microorganisms
}

\author{
Alicia Lara-Márquez, María G Zavala-Páramo', Everardo López-Romero², Nancy Calderón-Cortés',
} Rodolfo López-Gómez ${ }^{3}$, Ulises Conejo-Saucedo ${ }^{1}$ and Horacio Cano-Camacho ${ }^{1 *}$

\begin{abstract}
Background: Microorganisms produce cell-wall-degrading enzymes as part of their strategies for plant invasion/ nutrition. Among these, pectin lyases (PNLs) catalyze the depolymerization of esterified pectin by a $\beta$-elimination mechanism. PNLs are grouped together with pectate lyases (PL) in Family 1 of the polysaccharide lyases, as they share a conserved structure in a parallel $\beta$-helix. The best-characterized fungal pectin lyases are obtained from saprophytic/opportunistic fungi in the genera Aspergillus and Penicillium and from some pathogens such as Colletotrichum gloeosporioides.

The organism used in the present study, Colletotrichum lindemuthianum, is a phytopathogenic fungus that can be subdivided into different physiological races with different capacities to infect its host, Phaseolus vulgaris. These include the non-pathogenic and pathogenic strains known as races 0 and 1472, respectively.
\end{abstract}

Results: Here we report the isolation and sequence analysis of the Clpn/2 gene, which encodes the pectin lyase 2 of $C$. lindemuthianum, and its expression in pathogenic and non-pathogenic races of $C$. lindemuthianum grown on different carbon sources. In addition, we performed a phylogenetic analysis of the deduced amino acid sequence of Clpnl2 based on reported sequences of PNLs from other sources and compared the three-dimensional structure of Clpnl2, as predicted by homology modeling, with those of other organisms. Both analyses revealed an early separation of bacterial pectin lyases from those found in fungi and oomycetes. Furthermore, two groups could be distinguished among the enzymes from fungi and oomycetes: one comprising enzymes from mostly saprophytic/ opportunistic fungi and the other formed mainly by enzymes from pathogenic fungi and oomycetes. Clpnl2 was found in the latter group and was grouped together with the pectin lyase from C. gloeosporioides.

Conclusions: The Clpnl2 gene of C. lindemuthianum shares the characteristic elements of genes coding for pectin lyases. A time-course analysis revealed significant differences between the two fungal races in terms of the expression of Clpn/2 encoding for pectin lyase 2. According to the results, pectin lyases from bacteria and fungi separated early during evolution. Likewise, the enzymes from fungi and oomycetes diverged in accordance with their differing lifestyles. It is possible that the diversity and nature of the assimilatory carbon substrates processed by these organisms played a determinant role in this phenomenon.

\footnotetext{
* Correspondence: hcano1gz1@mac.com

${ }^{1}$ Centro Multidisciplinario de Estudios en Biotecnología, Universidad Michoacana de San Nicolás de Hidalgo, Km. 9.5 Carretera Morelia-

Zinapécuaro, Posta Veterinaria, Tarímbaro, C.P. 58000, Michoacán, México

Full list of author information is available at the end of the article
} 


\section{Background}

Pectin is one of the major components of the primary cell wall of plants and is also found in dividing cells and in the areas of contact between cells that have a secondary cell wall, including xylem and the fibrous cells of woody tissue. Pectin comprises approximately $35 \%$ of the primary cell wall of dicots and non-graminaceous monocots. Although its content in secondary walls is greatly reduced, it is believed that pectin plays an important role in the structure and function of both primary and secondary cell walls. The functions of pectin in cell walls are diverse and include plant growth and development, morphogenesis, defense, cell adhesion, cell wall structure, cellular expansion, porosity, ion binding, hydration of seeds, leaf abscission and fruit development, among others [1,2]. In general, pectin is considered to be a group of polysaccharides that are rich in galacturonic acid (GalA) and present in the form of covalently linked structural domains: homogalacturonan (HG), xylogalacturonan (XGA), rhamnogalacturonan I (RG-I) and rhamnogalacturonan II (RG-II) $[1,2]$. The main enzymes involved in the degradation of the HG backbone of pectin are polygalacturonases (PGA, E.C. 3.2.1.15 and XPG, E.C. 3.2.1.67), pectate lyases (PL, E. C. 4.2.2.9 and 4.2.2.2) and pectin lyases (PNL, E.C. 4.2.2.10) [3].

Pectin lyases (PNLs) catalyze the degradation of pectin through $\beta$-elimination; they remove a proton and generate an unsaturated bond between the C-4 and C-5 carbons of the non-reducing end of pectin, which is a neutral form of pectate in which the uronic acid moiety of galacturonic residues has been methyl-esterified. The activity of PNLs is highly dependent on the distribution of the methyl esters over the homogalacturonan backbone. PNLs exhibit $\mathrm{pH}$ optima in the range of 6.0-8.5 and, unlike PLs, their activity is independent of $\mathrm{Ca}^{2+}$ ions; it is believed, however, that the residue $\mathrm{Arg}^{236}$ plays a role similar to that of $\mathrm{Ca}^{+2}$ $[4,5]$. Pectinase gene expression is regulated at the transcriptional level by the $\mathrm{pH}$ of the medium and by carbon sources, as it is induced by pectin and pectic components and repressed by glucose [6-8].

PNLs are grouped into Family 1 of the polysaccharide lyases [9] and into the pectate lyase superfamily that, in addition to pectin lyases and pectate lyases, also includes plant pollen/style proteins. The three-dimensional structures of five members of the pectate lyase superfamily have been determined. These include Erwinia chrysanthemi pectate lyase C (PELC) [10] and pectate lyase E (PELE) [11], Bacillus subtilis pectate lyase [12] and Aspergillus niger pectin lyase A (PLA) [13] and pectin lyase B (PLB) [14]. These enzymes fold into a parallel $\beta$-helix, which is a topology in which parallel $\beta$-strands are wound into a large right-handed coil [15]. Although PLs and PNLs exhibit a similar structural architecture and related catalysis mechanisms, they nonetheless diverge significantly in their carbohydrate binding strategy $[4,13]$. Currently, strategies are available for developing functional information from three-dimensional images of enzymes. The growing number of databases on the structure of pectinolytic enzymes has facilitated the analysis of minor structural differences that are responsible for the specific recognition of a unique oligosaccharide sequence in a heterogeneous mixture [4].

Most of the available information about fungal PNLs and their corresponding encoding genes has been obtained from saprophytic/opportunistic fungi such as Aspergillus niger [16-19], A. orizae [20,21], A. fumigatus [22], Penicillium griseoroseum [23], P. occitanis [24] and to a lesser extent from the phytopathogenic fungi Glomerella cingulata [25] and C. gloeosporioides [26].

The ascomycete $C$. lindemuthianum is an economically important phytopathogen, and along with its host Phaseolus vulgaris, it provides a convenient model to study the physiological and molecular bases of plantpathogen interactions [27]. It is an intracellular hemibiotrophic pathogen with physiological races that invade the plant in an interaction consistent to the gene-forgene model [28], and monogenic dominant resistance in common bean cultivars leads to the appearance of localized necrotic spots typical of the hypersensitive response (HR) [29]. After penetration of a host epidermal cell in a susceptible cultivar, the pathogenic races of C. lindemuthianum develop an infection vesicle and extend into adjacent cells by producing large primary hyphae, which invaginate without penetrating the host cell membrane and thus persist as a biotrophic interaction. Once a large area of the plant tissue has been colonized, necrotrophic hyphae develop [29], and this step closely correlates with the production of a number of host cell-wall-degrading enzymes that are characteristic of phytopathogenic fungi [30-32]. Up to know, race 0 is the only strain of $C$. lindemuthianum unable to infect $P$. vulgaris, which contrasts with 1472 , one of the most virulent races isolated in México [33]. This difference makes the two races an excellent model to investigate the role of pectinolytic enzymes in virulence of $C$. lindemuthianum. Previous results from this laboratory revealed significant differences between pathogenic (1472) and non-pathogenic (0) races of C. lindemuthianum in terms of growth and production of extracellular PNL activity on different carbon and nitrogen sources in liquid culture. Accordingly, race 1472 grew faster in media containing glucose or polygalacturonic acid, and on $92 \%$-esterified pectin, it produced levels of PNL activity that were approximately 2 -fold higher than those produced by race 0 . In contrast, cell walls isolated from $P$. vulgaris hypocotyls and, to a lesser degree, from 
cellulose sustained the growth of both races but induced PNL only in the pathogenic race [34].

Here we report the isolation and sequence analysis of the Clpnl2 gene, which encodes pectin lyase 2 of C. lindemuthianum, and its expression in pathogenic and nonpathogenic races of $C$. lindemuthianum in response to cultivation on different carbon sources. To determine the relationship among the three-dimensional structures of PNLs and the lifestyle of PNL-producing microorganisms, we performed a phylogenetic analysis using protein sequences and deduced amino acid sequences reported for PNLs. A comparative analysis of the three-dimensional structure of the Clpnl2 protein predicted by homology modeling, covering the main body of the protein and the carbohydrate binding site, and the three-dimensional structures of the PNLs used in the phylogenetic analysis was also performed.

\section{Methods}

\section{Strain and culture conditions}

C. lindemuthianum races 0 (non-pathogenic) and 1472 (pathogenic) were kindly provided by Dr. June Simpson (CINVESTAV-IPN, Unidad Irapuato, México) and maintained on potato dextrose agar (PDA, Difco) at $20^{\circ} \mathrm{C}$. For DNA extraction, mycelia from $C$. lindemuthianum race 1472 grown on potato dextrose (PD) for 9 days at $20^{\circ} \mathrm{C}$ with continuous shaking (150 rpm), was recovered by filtration through Whatman paper No. 1 and stored at $-85^{\circ} \mathrm{C}$. For induction, $1.6 \mathrm{mg}$ (about $5 \mathrm{~cm}^{2}$ ) of mycelia from races 0 and 1472 were inoculated in 250 ml-Erlenmeyer flasks containing $50 \mathrm{ml}$ of PD medium and shaken $(150 \mathrm{rpm})$ at $20^{\circ} \mathrm{C}$. After 9 days, mycelia was collected by filtration, washed with water and transferred to $250 \mathrm{ml}-$ Erlenmeyer flasks containing $50 \mathrm{ml}$ of modified Mathur's medium (10 mM MgSO $.7 \mathrm{H}_{2} \mathrm{O}, 20 \mathrm{mM} \mathrm{KH}_{2} \mathrm{PO}_{4}, 36 \mathrm{mM}$ $\mathrm{L}$-glutamic acid, distilled water up to $1 \mathrm{~L}$; final $\mathrm{pH}, 5.5$ ) [35] supplemented with either $2.5 \%$ glucose, $92 \%$-esterified pectin or cell walls from $P$. vulgaris. Flasks were shaken $(150 \mathrm{rpm})$ at $20^{\circ} \mathrm{C}$ and after different periods of growth, mycelia was collected by filtration, washed with water and stored at $-85^{\circ} \mathrm{C}$ until use.

\section{Preparation of plant cell walls}

Seedlings of $P$. vulgaris cv. Flor de Mayo were grown for 7 days, and cell walls were extracted and purified from hypocotyls as described elsewhere [36].

\section{DNA and RNA isolation}

Genomic DNA was isolated from C. lindemuthianum mycelia that had been grown for 9 days in PD medium according to standard protocols [37]. Total RNA was purified from mycelia using TRIzol reagent (Invitrogen). RNA samples were treated with DNAse I according to manufacturer's instructions (Invitrogen) to eliminate DNA. The quality and concentration of total RNA were verified using the RNA 6000 Nano LabChip kit (2100 Agilent Bioanalyzer).

\section{Isolation of the homologous DNA Clpn/2 probe from C. lindemuthianum}

Genomic DNA from race 1472 was amplified by PCR using the upstream primer pnlD (5'-CAGTACGTCTG GGGTGGTGA-3') and downstream primer pnlR (5'AAGTAGTTGTTGACGACGTGG-3', which are homologous to sequences between 595 and 614 nt and 891 and $911 \mathrm{nt}$, respectively, of exon 3 of the Clpnl2 gene from C. gloeosporioides [GenBank: AAD43565]. The PCR incubation mixture was heated at $95^{\circ} \mathrm{C}$ for $5 \mathrm{~min}$ in a thermocycler (Eppendorf Master Cycler Gradient, Brinkmann, Westbury, NY), followed by denaturation for $1 \mathrm{~min}$ at $95^{\circ} \mathrm{C}$, annealing for $2 \mathrm{~min}$ at $48^{\circ} \mathrm{C}$ and extension for $2 \mathrm{~min}$ at $72^{\circ} \mathrm{C}$. PCR was then performed for 35 cycles, followed by a final extension for $10 \mathrm{~min}$ at $72^{\circ} \mathrm{C}$. A PCR product of $383 \mathrm{bp}$ corresponding to $p n l 2$ gene (clpnl2 fragment) was ligated into the pCR 2.1 vector and introduced into E. coli TOP 10 strain from the TOPO TA Cloning kit (Invitrogen).

\section{Genomic DNA library construction and screening}

Partial Sau3AI digestion of genomic DNA from race 1472 was used to construct a genomic library in Lambda DASH II/BamHI according to manufacturer's instructions (Stratagene). Screening was performed using $15 \times 10^{4}$ UFP with three rounds of hybridization filters and the homologous Clpnl2 fragment, which was ${ }^{32} \mathrm{P}$-radiolabeled using the Radprime DNA Labeling System Life Technologies Kit (Tech-Line).

\section{Molecular cloning of the Clpn/2 full-length cDNA and expression analyses}

The cDNA was amplified by RT-PCR as specified by the manufacturer. SuperScript III First-Strand Synthesis System for RT-PCR (Invitrogen) was used to prepare cDNA from total RNA. PCR was performed using the upstream primer Pnl67 (5'-ATGAAGTCTACCATCTTCTCCG-3') and downstream primer Pnl1569 (5'-TTAGATCTTGCGAAACCGGC-3') designed from the DNA Clpnl2 genomic sequence of $C$. lindemuthianum. The PCR incubation mixture was heated at $94^{\circ} \mathrm{C}$ for $5 \mathrm{~min}$ in a thermocycler (Eppendorf Master Cycler Gradient, Brinkmann, Westbury, NY), followed by 30 cycles of denaturation for $20 \mathrm{sec}$ at $94^{\circ} \mathrm{C}$, annealing for $30 \mathrm{sec}$ at $54^{\circ} \mathrm{C}$, extension for $1.5 \mathrm{~min}$ at $72^{\circ} \mathrm{C}$ and then by a final extension for $7 \mathrm{~min}$ at $72^{\circ} \mathrm{C}$. A PCR product of $1,140 \mathrm{bp}$ obtained from total RNA of race 1472 induced with pectin for $4 \mathrm{~h}$ and corresponding to the Clpnl2 gene, was ligated into the pCR 2.1 vector (Invitrogen) and three clones were selected and sequenced. The 5' end of cDNA was amplified by 5'RACE as specified by the manufacturer ( $5^{\prime}$ RACE System for 
Rapid Amplification of cDNA Ends, Invitrogen), with total RNA from race 1472 induced for $4 \mathrm{~h}$ with $92 \%$-esterified pectin, using the specific reverse primers Pnl1249 (5'-GTA GTT GTT GAC GAC GTG GAC G-3') and Pnl975 (5'CGA TGT GCT GGC GGC CG-3'). The amplification products were cloned and five clones were selected and sequenced. For expression analysis, total cDNA (1140 pb) was amplified with specific primers Pnl67 and Pnl1569 in the same conditions described above using total RNA of mycelia from both races induced with $92 \%$-esterified pectin or cell walls from $P$. vulgaris for $2,4,6,8,10$ and $12 \mathrm{~h}$. For expression analysis, cDNA obtained from cells grown under different conditions was also amplified by PCR using oligonucleotides prepared from ribosomal 18S RNA as a control (5' - TTAGCATGGAATAATRRAATAGGA3'and 5'-ATTGCAATGCYCTATCCCCA-3) [38]. The PCR incubation mixture was heated at $94^{\circ} \mathrm{C}$ for $3 \mathrm{~min}$, followed by 35 cycles of denaturation for $1 \mathrm{~min}$ at $94^{\circ} \mathrm{C}$, annealing for $1 \mathrm{~min}$ at $56^{\circ} \mathrm{C}$, extension for $1 \mathrm{~min}$ at $72^{\circ} \mathrm{C}$ and then a final extension for $10 \mathrm{~min}$ at $72^{\circ} \mathrm{C}$. The cDNA of Clpnl2 and the amplified RT-PCR products were analyzed in a Bioanalyzer using the system for quantification and molecular size Agilent DNA 7500 (2100 Agilent Bioanalyzer).

\section{Southern blot hybridization}

Genomic DNA of mycelia from race 1472 was digested with selected restriction endonucleases. Digestion products were size-fractionated on a $0.8 \%$ agarose gel, transferred to a nylon membrane (Hybond-N+, Amersham Pharmacia Biotec, England), hybridized and detected with a ${ }^{32} \mathrm{P}$-radiolabeled Clpnl2 probe. Hybridizations were carried out at $60^{\circ} \mathrm{C}$ in $2 \mathrm{X} \mathrm{SSC}$ containing $0.5 \%$ blocking agent (Roche) and $0.1 \%$ SDS. After hybridization, the blot was washed at $60^{\circ} \mathrm{C}$ for 15 min with $2 \mathrm{X}$ SSC containing $1 \%$ SDS and then at $60^{\circ} \mathrm{C}$ for 15 min with $0.2 \mathrm{X}$ SSC containing $0.1 \%$ SDS.

\section{Sequencing and DNA analysis}

The sequences of both strands of DNA of race 1472 and cDNA of both races were determined by the dideoxy-chain termination method using the ABI Prism Dye Cycle Sequencing Ready Reaction Kit in an ABI PRISM 310 DNA sequencer (Applied Biosystems, Foster City, CA). The nucleotide sequences were analyzed using the DNAsis (Hitachi) and 4Peaks v 1.7.2 software (http://mekentosj. com). In silico analyses of putative transcription factor binding sites were performed using the AliBaba2.1 software [39] and the Transfac 7.0 database [40]; the regulatory sequences reported for genes of fungal lytic enzymes were also compared. The $\mathrm{N}$-terminal secretion signal sequence was identified with the SignalP 3.0 web server [41]. The protein molecular mass, $\mathrm{pI}$ and $N$-glycosylation sites were calculated on an ExPASy Proteomics Server [42].

\section{Phylogenetic analyses}

Phylogenetic analyses were performed on the Clpnl2 deduced amino acid sequence and the deduced amino acid sequences of 34 pectin lyases that were previously reported (Table 1). Protein sequences were aligned with Clustal $\times$ software [43] using default parameters. Prior to phylogenetic analyses, signal peptide sequences and $\mathrm{N}$-terminal and C-terminal extensions were excluded. Phylogenetic analyses were performed under Bayesian, maximum parsimony and neighbor-joining criteria, using the programs MrBayes Vs. 3.1.2 [44], PAUP*v 4b10 [45] and Mega 4 [46]. We used the amino BLOSUM G2 evolution model with gamma correction for Bayesian analysis. In total, 10,000 trees were obtained based on the settings ngen $=1000000$ and sample freq $=100$ for Bayesian criteria. Prior to estimating the support of the topologies that were found, we checked the convergence of overall chains (4) when the log likelihood values reached the stationary distribution. The first 2500 trees were 'burn-in' and discarded, and a 50\% majority rule consensus tree of the remaining trees was generated. For maximum parsimony analyses, the most parsimonious trees were estimated using the heuristic search option (TBR branch swapping, saving only a single tree in each case) with random sequence addition (five random replicates). Support was evaluated by bootstrap analysis using the full heuristic search option with 1000 replicates. For the neighbor-joining method [47], a JTT matrix was used, and 1000 bootstrap replicates were performed. We used the A. thaliana pectate lyase [GenBank: CAB41092] as an outgroup for pectin lyase analyses.

\section{Protein homology modeling}

The tertiary structure of the deduced amino acid sequence of Clpnl2 was predicted by homology modeling using the Swiss-Model Server [48] using Pel B from $A$. niger (PDB: 1qcxA) as template [14]. The prediction of three-dimensional structures of the deduced amino acid sequences used in the phylogenetic analysis was performed in a similar manner. The structural parameters and prediction quality of the modeled structures were evaluated using the program SPDBV v. 4.01 [49]. The energy minimization of the model was performed by GROMOS96 [50], which was provided by the SPDBV program. MMV 2010.2.0.0 (Molegro ApS) and SPDBV v. 4.01 were used for visualization of molecular structures.

\section{Multiple comparisons of protein structures}

The comparison of protein structures was performed using the Voronoi contact method [51] with the ProCKSIServer [52]. Calculations were performed using default parameters, and the resultant similarity matrixes (Voronoi-contacts) were standardized and used as the input for 
Table 1 Nucleotide and protein sequences of reported pectin lyases used for phylogenetic analyses

\begin{tabular}{ll}
\hline Microorganism & Access number \\
\hline Aspergillus niger & GenBank: CAD34589, GenBank: AAW03313, GenBank: CAA39305, GenBank: CAA01023, GenBank: ACE00421, GenBank: \\
Aspergillus nidulans & GenBank: ABF50854 \\
Aspergillus oryzae & GenBank: BAB82468, GenBank: BAB82467 \\
Aspergillus fumigatus & Swiss-Prot: BOYCL3, Swiss-Prot: Q4WV10, GenBank: EAL91586, Swiss-Prot: Q4W156 \\
Aspergillus terreus & GenBank: EAU31855, GenBank: EAU37973 \\
Aspergillus clavatus & GenBank: EAW12911 \\
Emericella nidulans & Swiss-Prot: Q5BA61 \\
Colletotrichum & GenBank: AAA21817, GenBank: AAD43565, GenBank: AAF22244 \\
gloeosporioides & GenBank: ABH03046 \\
Penicillium occitanis & GenBank: AF502280 \\
Penicillium griseoroseum & GenBank: EAW17753, Swiss-Prot: A1CYC2 \\
$\begin{array}{l}\text { Neosartorya fischeri } \\
\text { Pyrenophora tritici-repentis }\end{array}$ & GenBank: XP_001934252, GenBank: XP_001930850 \\
$\begin{array}{l}\text { Ustilago maydis } \\
\text { Verticillium albo-atrum }\end{array}$ & GenBank: EAK86184 \\
$\begin{array}{l}\text { Phytophthora infestans } \\
\text { Bacillus subtilis }\end{array}$ & GenBank: XP_003001443 \\
$\begin{array}{l}\text { Pectobacterium } \\
\text { atrosepticum }\end{array}$ & GenBank: BAA12119, GenBank: AAB84422 \\
Pectobacterium & GenBank: CAG74408 \\
carotovorum & GenBank: AAA24856 \\
\hline
\end{tabular}

clustering of the protein set using the un-weighted pair group method for the arithmetic mean (UPGMA) [53].

\section{Results and discussion}

\section{Isolation and sequence analysis of the Clpn/2 gene}

Nine positive clones were isolated from the screening of a C. lindemuthianum genomic library using the ${ }^{32} \mathrm{P}$-radiolabeled fragment of Clpnl2. Southern blot analysis of the clones allowed the identification of a $4.0-\mathrm{kb}$ fragment that hybridized with the PCR probe. The 4.0-kb fragment was subcloned, and 2,159 bp containing the Clpnl2 gene was sequenced [GenBank: JN034038]. The full-length Clpnl2 cDNA of races 1472 [GenBank: JN034039] and 0 [GenBank: JN653459] obtained by RT-PCR from total RNA of mycelium induced for $4 \mathrm{~h}$ with $92 \%$-esterified pectin, was sequenced using specific primers designed from the Clpnl2 gene sequence.

The analysis of the cDNA sequences showed no differences between the two races. The coding region of the Clpnl2 gene consisted of $1428 \mathrm{bp}$ interrupted by four introns ranging in size from 60 to $87 \mathrm{bp}$ (Figure 1). According to the 5'RACE analysis, a putative transcription starting point was localized [19], and the context of the start codon ATG matched with the Kozak sequence for filamentous fungi [54]. Two possible regulatory sequences were identified in the 5' untranslated region of Clpnl2: a putative regulatory sequence for binding to RAP1, which is a transcriptional factor that participates in the activation of transcription and the silencing of genes in yeast cells, located at position +54 [55] and a possible binding sequence for the transcription factor $\mathrm{AbaA}$ at position +69. AbaA binding sites have been observed in several genes that participate in the control of cell development in organisms such as $A$. nidulans and the dimorphic fungus P. marneffei, where AbaA has been related to morphogenesis and dimorphism, respectively [56,57]. These putative regulatory elements were localized downstream the transcription site which is an uncommon finding. Multiple binding sites to AbaA have been reported in cis regulatory regions and some downstream the transcription starting site in A. nidulans genes. No attempts were made in this study to determine the function of these elements. Due to the size of the promoter region of Clpnl2, it was not possible to locate more elements commonly found in genes encoding for pectinolytic enzymes. The 5' and 3' untranslated regions (5'UTR and 3'UTR) were 129 and $563 \mathrm{bp}$, respectively. Two consensus sequences (AATAAA and TTTCACTGC) found in the terminal regions of eukaryotic mRNAs [58], and two of the three consensus sequences for yeast 3'-terminal regions (TAGT and YIT) [59] were detected in the Clpnl2 3'UTR.

The Clpnl2 cDNA contains an ORF of 1140 nucleotides that encodes a putative protein of 379 aa with a Nterminal secretion signal sequence of 19 amino acids, according to the SignalP 3.0 web server [41]. A protein of molecular mass $37.4 \mathrm{kDa}$ and a $\mathrm{pI}$ of 9.1 was calculated, and one potential $\mathrm{N}$-glycosylation site was located at position 110 (ExPASy Proteomics Server) [42]. These 


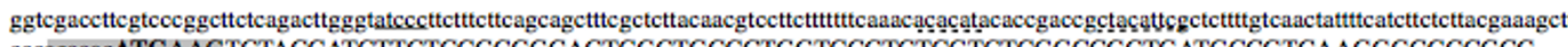
cceacaaacATGAAGTCTACCATCTTCTCCGCGGCACTGGCTGCCCTGGTCCCTCTCGTCTCGGCCGCTGATGCCGTCAAGGGCGCCGCC

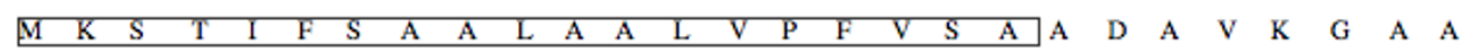
GAAGGCTTTGCCAAGGGCGTCACCGGTGGTGGCAGCGCCTCTCCCGTCTACCCTAAATCTAACGCCGAGCTCGCCTCCTACCTGAAG

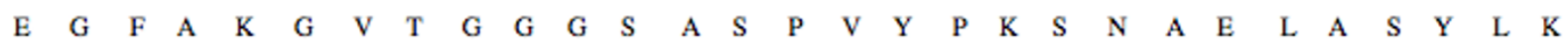
GACTCCTCCGCCCGCGTCATCGTCCTCACCAAGACGTTCGACTTTACCGGAACCGAGGGAACCGCCTCCGAGACTGGATGTGCCCCT

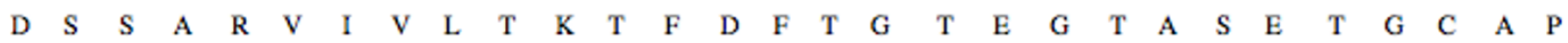
TACGGCACTGGCTCTGCTTGCCAGATTGCCATCAACAAGGACAACTGgttcgtgctttcacgatggettcaccggcettcactttcgacaatgtgcetggcegggagcaaga

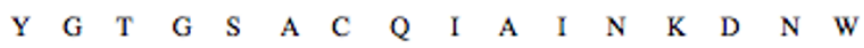
agaaagctgactgtttgaaagGTGCACCAACTACCAGCCCAACGCCCCCAAGGTCTCCGTCAAGTACGACAAGgtgagcagagcaatcettgagtctttcgactcttc

$$
\begin{array}{lllllllllllllllllll}
C & T & N & Y & Q & P & N & A & P & K & V & S & V & K & Y & D & K
\end{array}
$$

ccactgtgtgtttocctgegtttgctgactetctgtgectagGCCTCCTTCAGCCCCCTTATCGTTGGAAGCAACAAGTCCCTCATCGGCCAGGGCTCCAAGGGTG

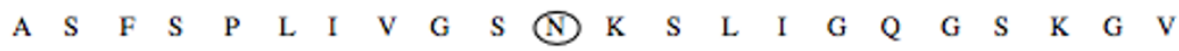

TCATCAAGGGCAAGGGTATCCGCATCAGCAACAACGCCAAGAACGTTATCGTCCAGAACgtgagtcgctcgecgacgacacgccgacgagaagcctgtgacta

$$
\begin{array}{lllllllllllllllllllllllllllllll}
I & K & G & K & G & I & R & I & S & N & N & A & K & N & V & I & V & Q & N
\end{array}
$$

acttactcgttgattccagATTCACATCACCCAGCTCAACCCGCAGTACGTCTGGGGCGGTGATGCCGTCTCCCTGGACGGCTCCGACCTGGTCTG

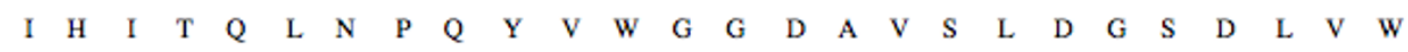
GATCGACCACGTCAAGACCTCCCTGATCGGCCGCCAGCACATCGTCCTCGGCAACGGCGCCAACAACCGCGTCACCATCTCCAACAA $\begin{array}{llllllllllllllllllllllllllllllllll}\text { I } & D & H & V & K & T & S & L & I & G & R & Q & H & I & V & L & G & N & G & A & N & N & R & V & T & I & S & N & N\end{array}$ CGAGATTGACGGCTCCACCTCCTGGTCCGCCACCTGCGACAACCACCACTACTGGGGCGTCTACCTCACCGGCAGCAACGACCTGGT

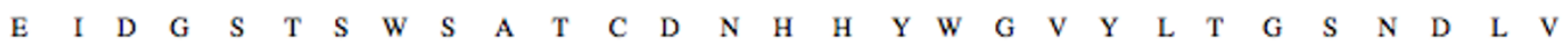
CACCTTCAAGAgtgagcagcgtctcttcaacaaattctgagcacgagaactgacaagtgacatcacaacagGCAACTACATCCACCACACCTCCGGCAGAGCCCCCAAG $\begin{array}{llllllllllllllllllllll}T & F & K & S & \text { N } & \text { Y } & \text { I } & \text { H } & \text { H } & \text { T } & S & G & R & A & P & K\end{array}$ ATCGCCGGCAACTCCCTCGTCCACGTCGTCAACAACTACTTTTACGACAACACCGGCCACGCCATGGAGGCCGACGCCGGCGCCAAG $\begin{array}{lllllllllllllllllllllllllllllllllllllllll}\text { I } & A & G & \text { N } & \text { S } & \text { L } & \text { V } & \text { H } & \text { V } & \text { V } & \text { N } & \text { N } & \text { Y } & \text { F } & \text { Y } & \text { D } & \text { N } & \text { T } & \text { G } & \text { H } & \text { A } & \text { M } & \text { E } & \text { A } & \text { D } & \text { A } & G & \text { A } & \text { K }\end{array}$ GTCGTCCTCGAGGGCAACATCTTCCAGAACGTAAAGGCCGCCATGCAGACCGGCCTCGCCGGCAAGGTCTTCTCCTCCCCGGACAAC

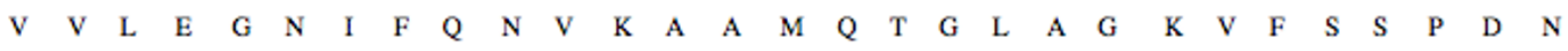
AACGCCAACAAGGCCTGCTCCGGCAAGCTCGGCCGCGCCTGCCAGCTCAACGCCTACGGCACCTCCGGCTCCCTCTCCGGCTCCGAC

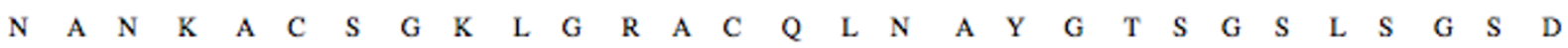
TCGAGCTTCCTCGGCAGCTTTGCCGGCAAGAACGTTGCTTCCGCGGGTAACTCCAACAATGCCAAGACGGCCCAGACCAGCGCCGGT

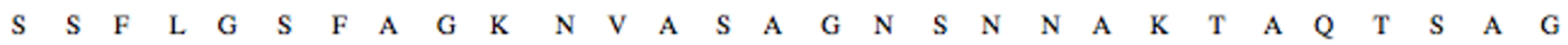
TTCGGCAAGATCTAAactgcgettggtagattgcctctcctcttgaacgggattcaatggtatttggagagcgtggtggtggttgagaggaagttgagtcgaggctagcgcagtgaccaacgactgattcatg F $\quad G \quad K \quad I \quad *$

tacatatcttacttaccgtcgaggacgtaaatacaatgettgatgcatcttaatacttcacctcggtttgcttcctaacgggaatattcttgatgegtttcttcgcagcttgcagacatggaattcgttcatcgttgaaggtocggac ctccgagtgggtctccggegøcgaaaatctcgggtcccgtgcaccatcccgatggcagcaattgcaattccggctagcgtaaagcaacgaaaagagcaaccaagatctgtttgctgacattcgagcaattgagcgctgcgc caagtgaaaagagccagttacttocgtcgtaccacaccetcttgaggtaactgcctatcgattaccacgtcgcgcatgacacttgtctggatgtgatcattcatcttactagtcacaagtataaacttactcgatgatgtgcactgg cttatc

Figure 1 Nucleotide and deduced amino acid sequence of the Clpnl2 gene. Intron and exon sequences are in lowercase and uppercase, respectively. The signal peptide sequence is boxed. The possible binding sequences of RAP1 and AbaA are underlined with a dotted line. The putative transcription start point is underlined, and the putative Kozak sequence is shaded. The sequences of the $3^{\prime}$-terminal region are underlined. An asterisk $\left(^{*}\right)$ marks the translation stop codon. The potential N-glycosylation site is circled. This sequence has been deposited in the GenBank nucleotide sequence database under accession number JN034038.

results are consistent with those reported for the amino acid sequences of Pnl2 and pnlA of C. gloeosporioides $[25,26]$. Despite $N$-glycosylation is common in pectinolytic enzymes and has been reported in several fungal pectin lyases al similar positions, little is known about the function of this posttranslational modification. Although it is believed that it affect enzyme stability and activity $[60,61]$.

\section{Southern blot analysis}

The genomic organization of the Clpnl2 gene was investigated by Southern blot analysis. Total DNA was digested with the restriction endonucleases $B a m H I$, EcoRI, Hind III, XhoI, EcoRI/BamHI and Hind III/XhoI. The digested DNA was fractionated on a $0.8 \%$ agarose gel and hybridized to the ${ }^{32} \mathrm{P}$-radiolabeled Clpnl2 probe. As depicted in Figure 2, commonly a single hybridization 


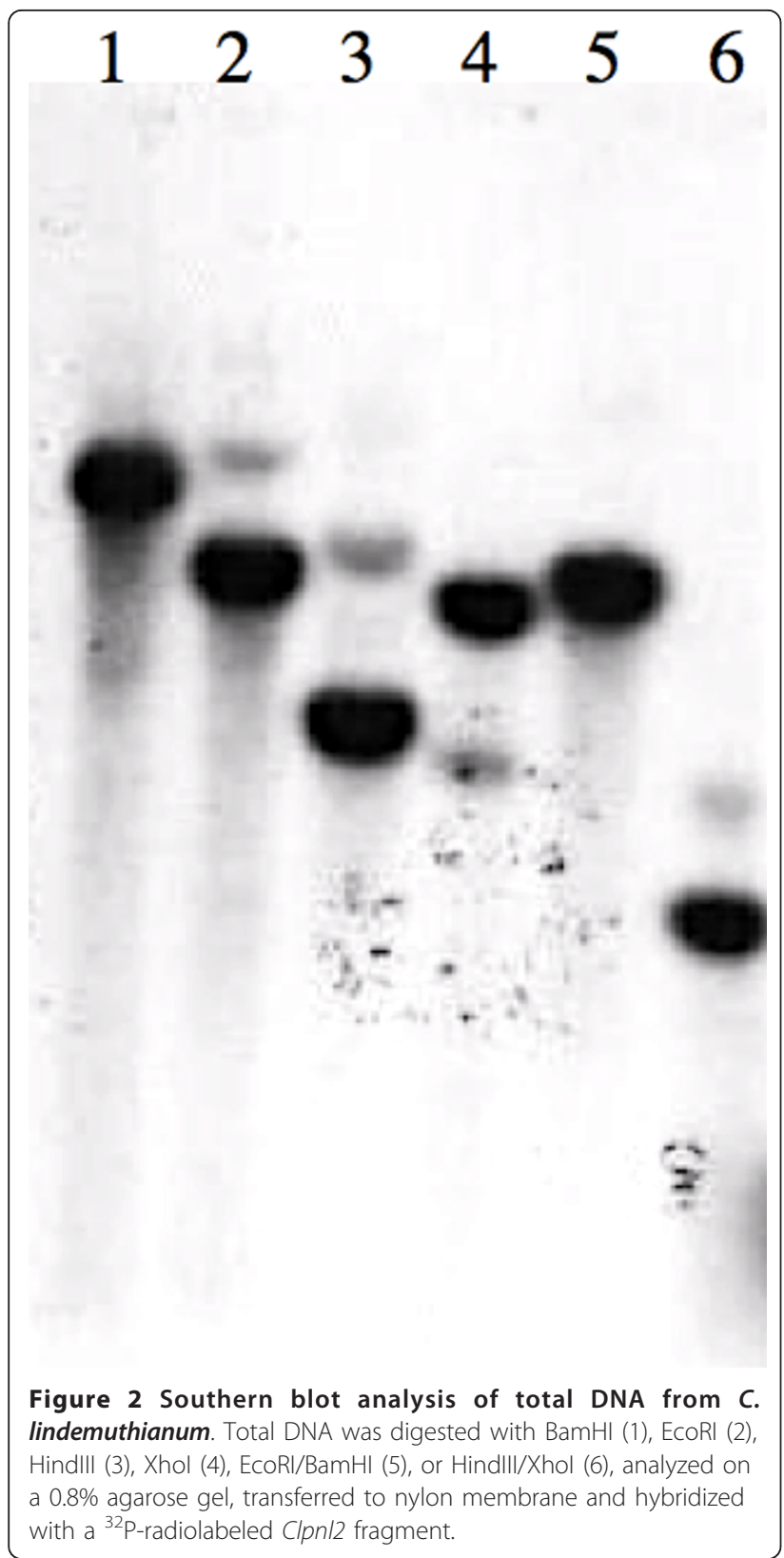

product was detected. In addition, a very faint signal probably resulting from hybridization with another gene of low similarity was observed. These results suggest that the $C$. lindemuthianum genome contains a single copy of the Clpnl2 gene, as does C. gloeosporioides [26].

\section{Protein homology modeling}

The tertiary structure of Clpnl2 predicted by homology modeling coincided with the typical topology of the parallel $\beta$-helix of PNLs (Figure 3). After energy minimization, the energy value was $-17418.428 \mathrm{~kJ} / \mathrm{mol}$, and the quality of the model generated was assessed by plating dihedrals $\Phi$ and $\Psi$ onto Ramachandran plots (SPDBV v.

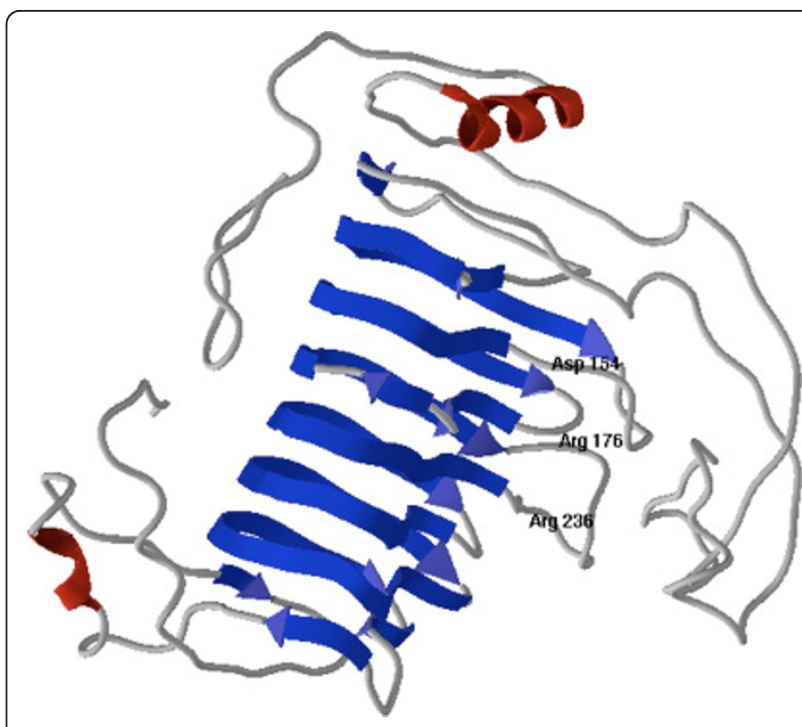

Figure 3 Three-dimensional structure of Clpn/2 from C. lindemuthianum showing highly conserved residues involved in catalysis.

4.01) [49]. The results are in agreement with the requirements for preferred and allowed regions, except for 3 non-glycine residues $(0.8 \%)$.

\section{Phylogenetic analyses}

To elucidate the relationship of Clpnl2 from C. lindemuthianum with bacterial, oomycete and fungal pectin lyases, sequences reported in databases were analyzed. Protein or deduced amino acid PNL sequences from 14 fungal species including: basidiomycetes, ascomycetes and one oomycete species, three bacterial species, and a pectate lyase sequence from $A$. thaliana as an external group, were used to generate phylogenetic trees. Clustal alignment used for phylogenetic analysis (Figure 4) allowed to determine the location of amino acids expected to have a catalytic role in the PNLs $[4,13]$. Asp $^{154}$ and Arg $^{176}$ (numbered from A. niger PELA) are conserved in fungi and oomycetes, although $\mathrm{Arg}^{176}$ could not be located in P. griseoroseum [GenBank: AF502280], and Arg ${ }^{236}$ is conserved in all analyzed sequences. Additionally, several conserved domains among the sequences of fungi and oomycetes were observed, and some of these were shared with bacterial amino acid sequences.

The trees inferred by the maximum parsimony (MP) and neighbor-joining (NJ) methods showed less resolution than those built by Bayesian analysis, as they had a number of unresolved branches. The general topology obtained is represented by the Bayesian $50 \%$ majority rule consensus tree, in which the Bayesian posterior probabilities, MP and NJ bootstrap support are indicated on the branches (Figure 5). 


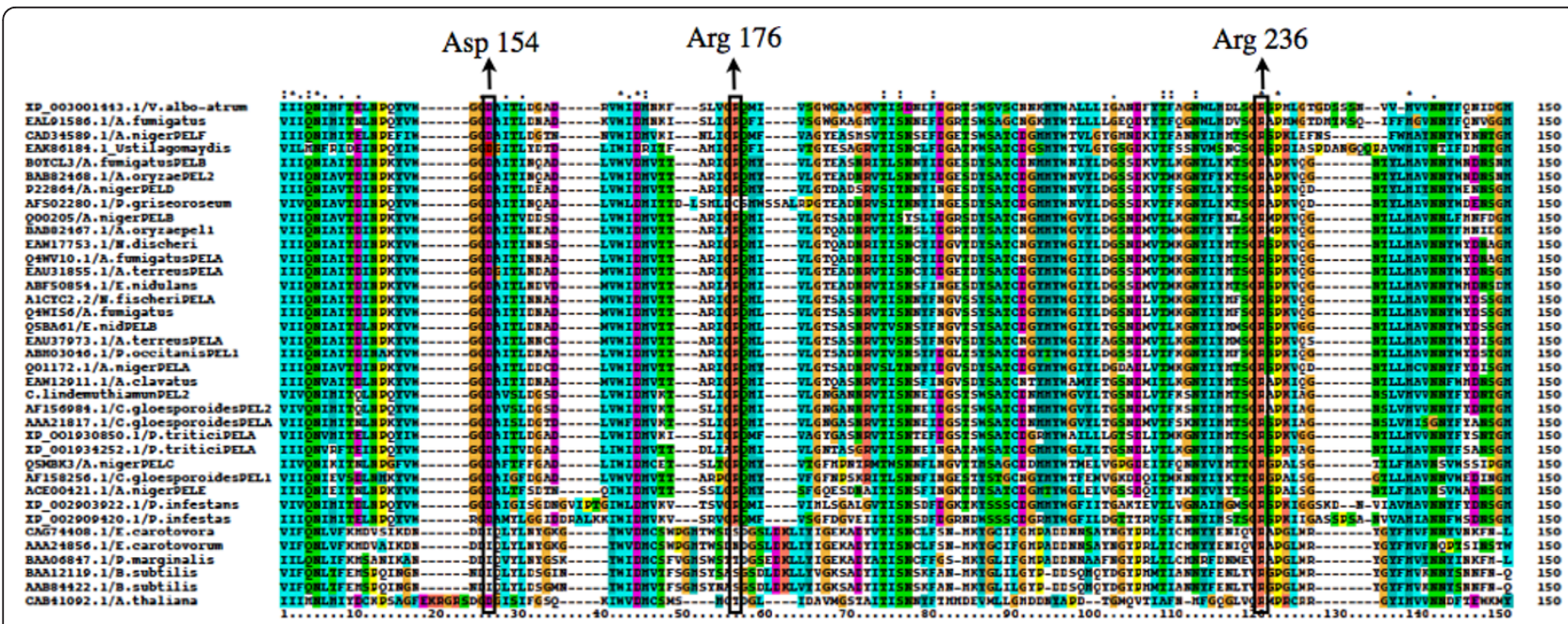

Figure 4 Alignment of the amino acid sequences of pectin lyases of bacteria, fungi and oomycetes used in phylogenetic analyses Identical residues are marked with an asterisk $(*)$. Dashes represent gaps introduced to preserve alignment. Conserved catalytic residues are indicated in boxes.

Bayesian analysis allowed the separation of pectin lyases into two groups: one representing bacteria with $100 \%$ posterior probability and $100 \%$ bootstrap support for MP and $\mathrm{NJ}$ analysis, and the other one representing fungi and oomycetes with $100 \%$ posterior probability and $98 \%$ bootstrap support for NJ. In the group formed by bacteria, sequences from Pectobacterium atrosepticum, P. carotovorum and Bacillus subtilis cluster together with 100\% posterior probability. This early separation between amino acid sequences of bacteria and those of oomycetes and fungi can be explained in terms of the evolution of lytic enzymes in these microorganisms for different purposes. Bacteria and some anaerobic fungi produce multi-enzymatic complexes called cellulosomes, which are anchored to the cell surface, allow the microorganisms to bind to lignocellulose substrates and increase the breakdown efficiency of cellulose, hemicellulose and pectin $[62,63]$. In contrast, in the majority of fungi and oomycetes, cellulases, pectinases and hemicellulases are not integrated in cellulosome complexes, and the pectin degradation is regulated by a multifunctional control system in which the enzymes act in a synergistic manner and are induced by monosaccharides or small oligosaccharides that are generated as products of the same enzymatic reactions $[64,65]$.

The inferred tree also showed that the analyzed sequences of saprophytic/opportunistic fungi are clustered into a monophyletic group with $98 \%$ posterior probability and $75 \%$ and $70 \%$ bootstrap support for MP and NJ analyses, respectively. However, phytopathogenic fungi and oomycetes were not clustered together. This may be the result of a reduced representation of sequences in the analysis arising from the few PNL sequences reported for members of these groups.
C. lindemuthianum is found clustered with the amino acid sequences of PnlA and Pnl2 of the fungal pathogen C. gloeosporioides with $100 \%$ posterior probability for Bayesian analysis as well as $96 \%$ and $99 \%$ bootstrap support for MP and NJ analysis, respectively.

Pectin and pectate lyases fold into a parallel $\beta$-helix, in which a high structural conservation occurs in regions distant from the active site and particularly in those that contribute to the parallel $\beta$-helix architecture. The binding cleft and surroundings constitute the most divergent part of the molecule, which allows variation in substrate specificity $[13,15]$. On this background, the results of the phylogenetic analyses and the fact that the classification of the pectin lyases is based both on amino acid sequence similarities as well as their structural features [9], we believe that a structural comparison would help to strengthen the phylogenetic analysis and to establish a relationship between the genes encoding PNLs with their three-dimensional structures involved in carbohydrate binding.

\section{Multiple comparisons of protein structures}

Once the tertiary structure of Clpnl2 was predicted, the tertiary structures corresponding to the amino acid sequences used in phylogenetic analyses and covering the central body of the enzyme including the carbohydratebinding site of these proteins were predicted and evaluated. The multiple comparisons of protein structures led to the formation of two clusters: one composed of the structures corresponding to the amino acid sequences of bacteria and another that was composed of fungal and oomycete structures (Figure 6). Furthermore, in agreement with the phylogenetic analyses, it was possible to 


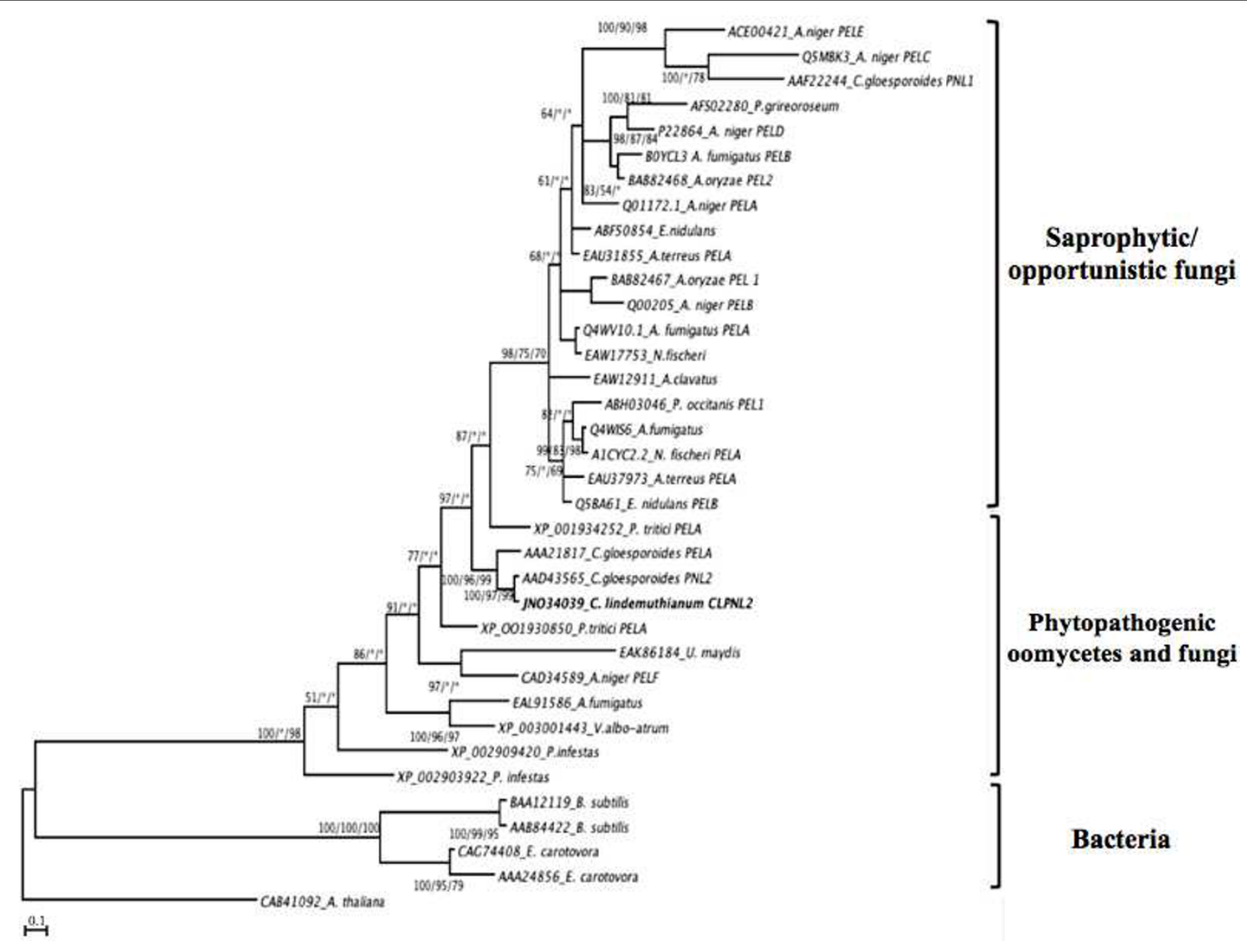

Figure 5 Phylogenetic tree of pectin lyases. The phylogeny shown is the Bayesian topology and branch lengths inferred using MrBayes vs. 3.1.2, with the Blosum $62+G$ model. Numbers above the diagonal indicate posterior probability values from Bayesian analysis. Numbers below the diagonal indicate bootstrap percentage values from a bootstrap analysis inferred using the same alignment with PAUP*4.0 and Neighbor-J, respectively. A. thaliana pectate lyase was used as an outgroup. The asterisks represent branches that were not supported in 50\% or more of the bootstraps. The scale bar represents the number of substitutions per site. The phylogenetic tree was edited using Dendroscope software [77].

distinguish the cluster formed mainly by sequences of fungi and oomycete pathogens, including Clpnl2, from the cluster formed by saprophytic/opportunistic fungi. Nevertheless, this analysis clustered the fungal sequences in two clearly defined groups: fungi and oomycete pathogens and saprophytic/opportunistic fungi. These results strongly support the notion that there is a close relationship between the tertiary structure of PNLs and the lifestyle of the microorganisms. The training of these groups was also observed for the elimination method FAST [66] and the hybrid heuristic URMS/RMS approach [67] using the ProCKSI-Server [52] (data not shown). Comparative modeling techniques and multiple comparisons of three-dimensional structures have been utilized for different purposes (e.g., searching for putative biological functions, drug design, protein-protein interaction studies). However, to our knowledge, this is the first study that uses a comparative analysis of protein structure in combination with a phylogenetic analysis to explore the evolution of lifestyle. We believe that a structural analysis can be an important tool for studying the evolution of microorganisms and their enzymes, since structural differences may reflect other important properties such as substrate specificity and others that can not be inferred from the analysis of amino acid sequences only.

\section{Expression analysis of Clpnl2}

Analysis of the Clpnl2 transcript in cells grown with glucose as the carbon source showed similar low basal levels of expression in the 0 and 1472 races (Figure 7C). When grown on cell walls, levels of Clpnl2 transcript in the pathogenic race, 1472, increased quickly after $2 \mathrm{~h}$, reached a peak after $6 \mathrm{~h}$, started to decrease and then again increased, giving a maximal value after $12 \mathrm{~h}$ of incubation (Figure 7B and 7C). Race 0 exhibited different expression kinetics: the amount of transcript peaked 


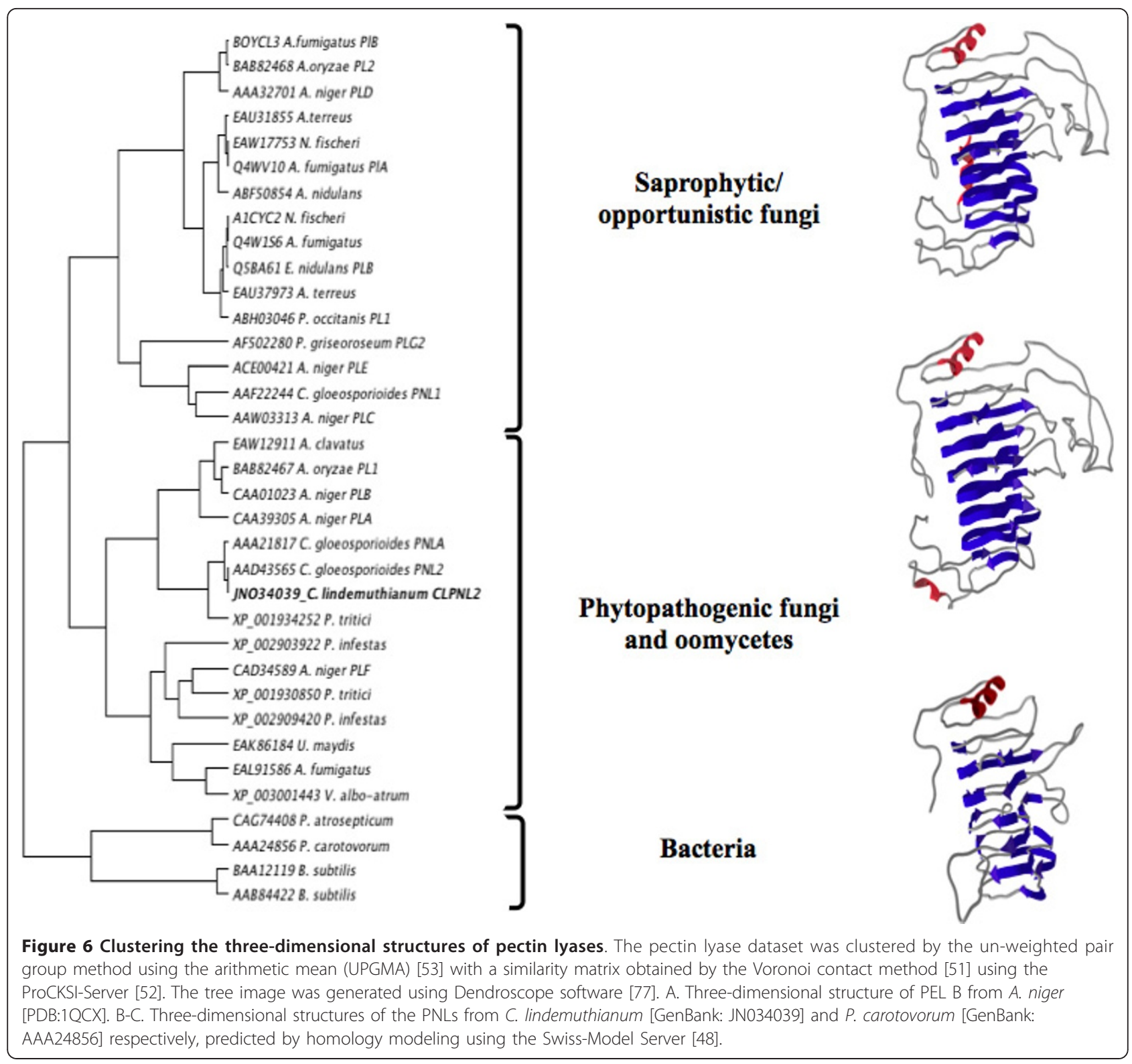

after $6 \mathrm{~h}$ and then fell to undetectable levels after $10 \mathrm{~h}$ (Figure 7A and 7C). At all time points between 2 and 8 $\mathrm{h}$, expression levels were lower than those observed in the pathogenic race. The transcript was expressed again after $12 \mathrm{~h}$ but at levels that reached only $23 \%$ of those observed in the pathogenic race.

The differences between the two races were much more noticeable when $92 \%$ esterified pectin was used as the sole carbon source. Transcript expression in the pathogenic race started to increase rapidly, reached the highest levels after 4-6 $\mathrm{h}$ and then started to decline, giving a still significant increase at the end of the experimental period (Figure $7 \mathrm{~B}$ and $7 \mathrm{C}$ ). The maximum transcript levels on this substrate were clearly higher than those observed on glucose. In contrast, the levels of the Clpnl2 transcript in the non-pathogenic race remained undetectable after $8 \mathrm{~h}$ of incubation. Late expression occurred after 10-12 h of cultivation, reaching values comparable to those observed after $4 \mathrm{~h}$ of culture on cell walls (Figure 7A and 7C). These results agree with the differences found by Hernández et al. [34], who analyzed the extracellular activity of pectin lyase in both races of $C$. lindemuthianum under the same conditions employed in this study. When both races were grown with glucose, extracellular PNL activity was barely detected after 8 (race 1472) and 10 (race 0) days of incubation, as observed in this study. Plant cell walls from $P$. vulgaris induced a similarly low PNL activity in the 


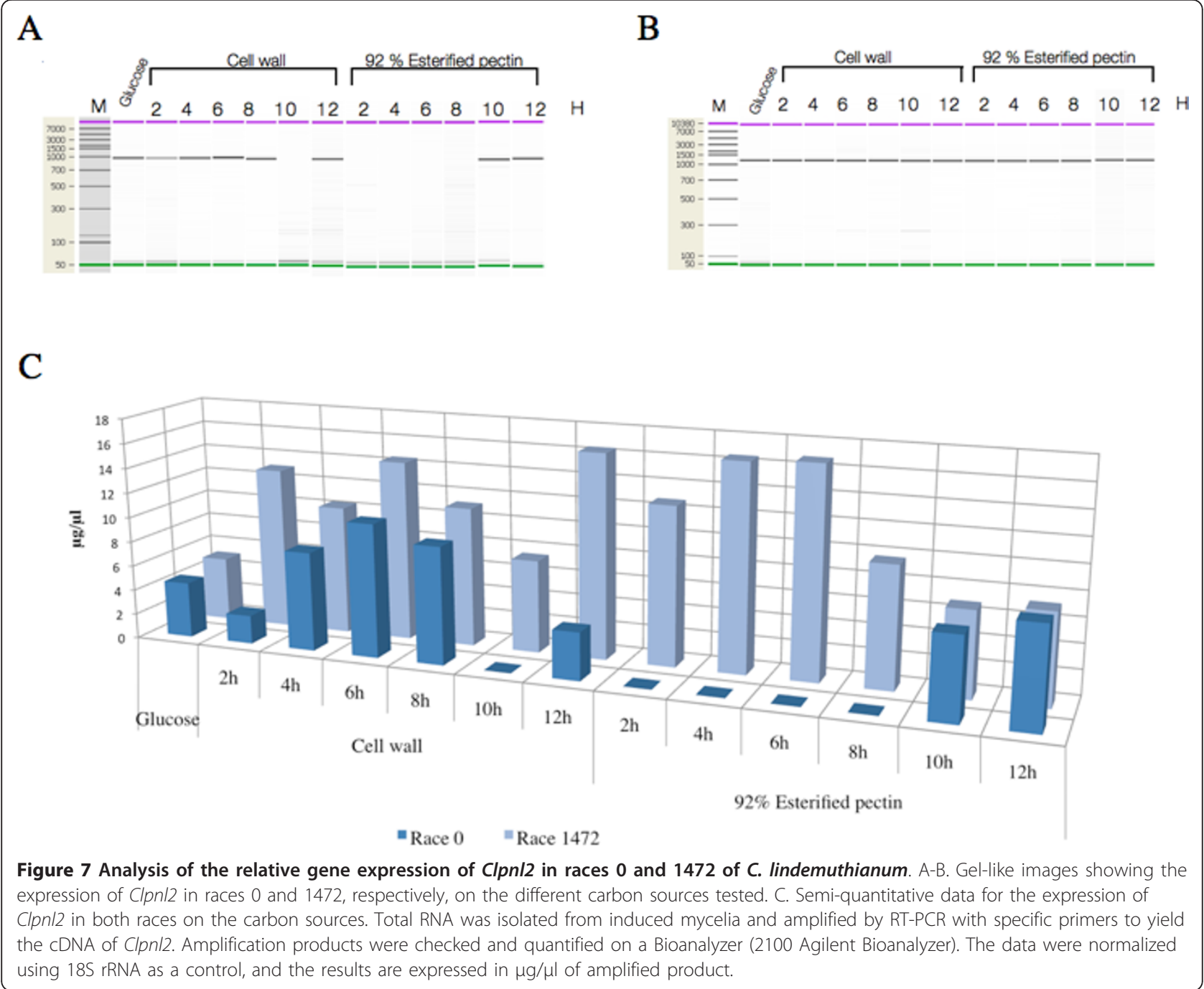

two isolates after 7-8 days of incubation. When pectin esterified to $92 \%$ was used as the carbon source, the activity in the pathogenic race nearly doubled compared with the activity in the non-pathogenic race. Early transcription of genes encoding lytic enzymes and late detection of the corresponding activities is a well documented phenomenon in different fungi $[8,30,65,68]$. Apart from the presence of a regulatory system controlling gene expression, the production of active pectinase and probably other lyticases can be modulated by other mechanisms such as postranslational modification and protein transport [69]. These alternatives may help to explain the differences observed in this study.

The pectin lyase of the pathogenic race of C. lindemuthianum is able to degrade highly esterified pectin (92\%), unlike that of the non-pathogenic race. Apparently, the differences between the pathogenic and nonpathogenic races of $C$. lindemuthianum occur as much at the expression level as at the level of enzymatic activity, and it is clear that the non-pathogenic and pathogenic races of C. lindemuthianum respond of different form to the carbon sources (except for glucose, where the mRNA of Clpnl2 and the active enzyme is synthesized at basal levels).

It has been proposed that the basal level of enzymatic activity breaks down the substrate, generating degradation products that further induce enzymatic activity [64]. A similar behavior has been observed in our laboratory for other enzymes that degrade cell walls, such as cellulases and the xylanase and $\beta$-xylosidase of C. lindemuthianum (unpublished data).

Several studies have reported that the pectinolytic enzymes play an important role in pathogenesis [70,71]. These are the first enzymes that act during the infection of the plant, causing extensive degradation of the cell wall and the main symptoms of the disease [72]. However, in addition to enzyme production, the sequence in which the enzymes are produced, the speed of synthesis, 
concentration and diffusion of enzyme are also fundamental aspects of the pathogenesis process [72]. The non-pathogenic race of $C$. lindemuthianum used in this work is unable to infect $P$. vulgaris, and thus its lifestyle is closer to that of a saprophytic fungus. Therefore, it is possible that the differences found between the nonpathogenic (0) and pathogenic (1472) races of C. lindemuthianum are related to the speed of activation of the lytic enzyme genes during the interaction with the host.

The number of pectin lyase sequences corresponding to different species of saprophytic/opportunistic fungi used in our analysis surpassed those of pathogenic oomycetes and fungi. This may be because more species of saprophytic/opportunistic have been studied and their degradation systems are better known. Alternatively, the enzymatic diversity may be the evolutionary effect of the heterogeneity of substrates that were encountered during interactions with an extended variety of hosts. For pectate lyases, it has been proposed that differences in the degree of pectin methylation can explain the existence of isozymes [4].

Pathogenic fungi and those who have close relationships with their host have developmental strategies that allow them to avoid the plant defenses and penetrate cell walls through the use of lytic enzymes. Plants also rely on strategies that allow them to detect and to defend against the attack of pathogens by producing inhibitors of these enzymes $[70,73,74]$. It is therefore possible that the evolution of unique enzymes was induced in pathogenic fungi and that a greater variability of these enzymes was induced in those fungi with a saprophytic lifestyle, which would explain the presence of amino acid sequences and tertiary structures corresponding to enzymes of saprophytic/ opportunistic fungi located between the sequences of pathogenic fungi and oomycetes in the phylogenetic analysis and comparison of structures.

There is evidence that supports a relationship between lytic enzyme production and the lifestyles of fungi and oomycetes. For instance, the genome of the oomycete Hyaloperonospora arabidopsidis has lost several of its hydrolytic enzymes compared with Phytophthora sp., which is likely its ancestor [75,76]. According to an analysis of the hydrolytic profiles of saprophytic/opportunistic and pathogenic fungi using diverse substrates, the species of phytopathogenic fungi are more active than the non-pathogenic fungi on six of eight tested substrates [74]. It has also been observed that pathogenic fungi of monocotyledonous plants are better adapted to degrade the cell walls of monocotyledonous plants, and pathogens of dicotyledonous plants are better able to degrade the cell walls of dicotyledonous plants, reflecting the host preference [74].

\section{Conclusions}

The Clpnl2 gene, which was cloned from a genomic library of C. lindemuthianum, is a unique copy and contains the characteristic elements of a pectin lyase of Family 1 of polysaccharide lyases.

Phylogenetic analyses showed an early separation between the enzymes of bacteria and those of fungi and oomycetes as well as a tendency of the amino acid sequences of fungi and oomycetes to cluster together according to their lifestyle. These results were confirmed by multiple comparison analysis of structures. According to these results, we believe that is possible that the diversity and nature of the substrates processed by these microorganisms play a determining role in the evolution of their lifestyle. In addition, our results showed that both races of C. lindemuthianum express the Clpnl2 gene, although some differences are observed in the timing and level of expression: the pathogenic race responds faster and at higher levels than the non-pathogenic race. This suggests that there are at least two levels of determination of the lifestyle of the microorganisms: one related to the evolution of the enzymes and one concerning the regulation of the expression of the enzymes. In our model, one race of C. lindemuthianum behaves as a hemibiotrophic pathogen and, according to its inability to infect bean, the other race behaves as a saprophyte. Although this study included the analysis of pectin lyase 2 only, we have observed this behavior with other enzymes of the complex involved in the degradation of the cell wall suggesting that it may be a general phenomenon. The differences at this level can be part of the general response of the fungi to host components. However future studies comparing the enzymatic complex of degradation of more fungi species with different lifestyles are needed to confirm this hypothesis.

Finally, we consider this type of information to be of great importance for the study of the biotechnological potential of these enzymes, as the efficiency of the enzymes could depend on the complexity of the vegetal material to be processed and the lifestyle of organism that is the source of enzymes and/or genes.

\section{Acknowledgements}

The authors thank the financial support provided by the FOMIX CONACYTGobierno del Estado de Michoacán (project 2009-05 Clave 116208 to HCC) and CONACYT (scholarship granted to ALM and UCS). We thank Gerardo Vázquez Marrufo by its comments to manuscript.

\section{Author details}

${ }^{1}$ Centro Multidisciplinario de Estudios en Biotecnología, Universidad Michoacana de San Nicolás de Hidalgo, Km. 9.5 Carretera MoreliaZinapécuaro, Posta Veterinaria, Tarímbaro, C.P. 58000, Michoacán, México. ${ }^{2}$ Departamento de Biología, División de Ciencias Naturales y Exactas, Universidad de Guanajuato, Apartado Postal No. 187, Guanajuato, Gto. 36000 México. ${ }^{3}$ Instituto de Investigaciones Químico-Biológicas, Universidad Michoacana de San Nicolás de Hidalgo, Francisco J. Mujica S/N Col. Felicitas del Río, IIQB-Edif. B1, Morelia, Mich. 262, México.

\section{Authors' contributions}

ALM, MGZP and UCS carried out the experiments. ALM and NCC carried out data analysis. ALM, MGZP and HCC conceived and designed the study, guided data analysis, interpretation, and discussion, and wrote the 
manuscript with comments from ELR and RLG. ELR participate in biochemical interpretation of data and RLG participate in genomic library construction. All authors read and approved the final manuscript.

Received: 3 June 2011 Accepted: 9 December 2011 Published: 9 December 2011

\section{References}

1. Willats WG, McCartney L, Mackie W, Knox JP: Pectin: cell biology and prospects for functional analysis. Plant Mol Biol 2001, 47:9-27.

2. Mohnen D: Pectin structure and biosynthesis. Curr Opin Plant Biol 2008, 11:266-277.

3. de Vries RP, Visser J: Aspergillus enzymes involved in degradation of plant cell wall polysaccharides. Microbiol Mol Biol Rev 2001, 65:497-522.

4. Herron SR, Benen JA, Scavetta RD, Visser J, Jurnak F: Structure and function of pectic enzymes: virulence factors of plant pathogens. Proc Natl Acad Sci USA 2000, 97:8762-8769.

5. Jayani RS, Saxena S, Gupta R: Microbial pectinolytic enzymes: a review. Process Biochem 2005, 40:2931-2944

6. Prusky D, McEvoy JL, Leverentz B, Conway WS: Local modulation of host $\mathrm{pH}$ by Colletotrichum species as a mechanism to increase virulence. $\mathrm{Mol}$ Plant Microbe Interact 2001, 14:1105-1113.

7. Maldonado MC, Strasser de Saad AM, Callieri D: Catabolite repression of the synthesis of inducible polygalacturonase and pectinesterase by Aspergillus niger sp. Curr Microbiol 1989, 18:303-306.

8. de Vries RP, Jansen J, Aguilar G, Pařenicová L, Joosten V, Wülfert F, Benen JAE, Visser J: Expression profiling of pectinolytic genes from Aspergillus niger. FEBS lett 2002, 530:41-47.

9. Lombard V, Bernard T, Rancurel C: A hierarchical classification of polysaccharide lyases for glycogenomics. Biochem J 2010, 432:437-444

10. Yoder MD, Keen NT, Jurnak F: New domain motif: the structure of pectate lyase C, a secreted plant virulence factor. Science 1993, 260:1503-1507.

11. Lietzke $S E$, Yoder MD, Jurnak F: The three-dimensional structure of pectate lyase $E$, a plant virulence factor from Erwinia chrysanthemi. Plant Physiol 1994, 106:849-862.

12. Pickersgill R, Smith D, Worboys K, Jenkins J: Crystal structure of polygalacturonase from Erwinia carotovora ssp. carotovora. J Biol Chem 1998, 273:24660-24664

13. Mayans O, Scott M, Connerton I, Gravesen T, Benen J, Visser J, Pickersgill R, Jenkins J: Two crystal structures of pectin lyase a from Aspergillus reveal a ph driven conformational change and striking divergence in the substrate-binding clefts of pectin and pectate lyases. Structure 1997, 5:677-689

14. Vitali J, Schick B, Kester HC, Visser J, Jurnak F: The tree-dimensional structure of Aspergillus niger pectin lyase B at 1.7-A resolution. Plant Physiol 1998, 116:69-80.

15. Herron SR, Jurnak F: Mechanistic lessons from structural studies of the pectate lyases. In Advances in pectin and pectinase Edited by: Voragen F, Schols H, Visser Redited by The Netherlands: Klumer Academic Publishers 2003, 221-233.

16. Kusters-van Someren MA, Harmsen JAM, Kester HCM, Visser J: Structure of the Aspergillus niger pelA gene and its expression in Aspergillus niger and Aspergillus nidulans. Curr Genet 1991, 20:293-299.

17. Kusters-van Someren M, Flipphi M, de Graaff $L$, den Broeck van H, Kester $H$, Hinnen A, Visser J: Characterization of the Aspergillus niger pelB gene: structure and regulation of expression. Mol Gen Genet 1992, 234:113-120.

18. Harmsen JAM, Kusters-van Someren MA, Visser J: Cloning and expression of a second Aspergillus niger pectin lyase gene (pelA): Indications of a pectin lyase gene family in A. niger. Curr Genet 1990, 18:161-166.

19. Gysler C, Harmsen JA, Kester HC, Visser J, Heim J: Isolation and structure of the pectin lyase D-encoding gene from Aspergillus niger. Gene 1990, 89:101-108.

20. Kitamoto N, Yoshino-Yasuda S, Ohmiya K, Tsukagoshi N: A second pectin lyase gene (pel2) from Aspergillus oryzae KBN616: its sequence analysis and overexpression, and characterization of the gene products. $J$ Biosci Bioeng 2001, 91:378-381.

21. Kitamoto N, Yoshino-Yasuda S, Ohmiya K, Tsukagoshi N: Sequence analysis and overexpression of a pectin lyase gene (pel1) from Aspergillus oryzae KBN616. Biosci Biotechnol Biochem 2001, 65:209-212.

22. Nierman WC, Pain A, Anderson MJ, Wortman JR, Kim HS, Arroyo J, Berriman M, Abe K, Archer DB, Bermejo C, et al: Genomic sequence of the pathogenic and allergenic filamentous fungus Aspergillus fumigatus. Nature 2005, 438:1151-1156.

23. Bazzolli DS, Ribon AOB, de Queiroz MV, de Araújo EF: Molecular characterization and expression profile of pectin-lyase-encoding genes from Penicillium griseoroseum. Can J Microbiol 2006, 52:1070-1077.

24. Trigui-Lahiani $H$, Gargouri A: Cloning, genomic organisation and mRNA expression of a pectin lyase gene from a mutant strain of Penicillium occitanis. Gene 2007, 388:54-60.

25. Templeton MD, Sharrock KR, Bowen JK, Crowhurst RN, Rikkerink EH: The pectin lyase-encoding gene ( $p n l)$ family from Glomerella cingulata: characterization of pnlA and its expression in yeast. Gene 1994, 142:141-146.

26. Wei Y, Shih J, Li J, Goodwin PH: Two pectin lyase genes, pnl-1 and pnl-2, from Colletotrichum gloeosporioides $f$. sp. malvae differ in a cellulosebinding domain and in their expression during infection of Malva pusilla. Microbiology 2002, 148:2149-2157.

27. Perfect SE, Hughes HB, O'Connell RJ, Green JR: Colletotrichum: A model genus for studies on pathology and fungal-plant interactions. Fungal Genet Biol 1999, 27:186-198.

28. Flor H: Current status of the gene-for-gene concept. Annu Rev Phytopathol 1971, 9:275-296.

29. O'Connell RJ, Bailey J: Differences in the extent of fungal development, host cell necrosis and symptom expression during race-cultivar interactions between Phaseolus vulgaris and Colletotrichum lindemuthianum. Plant Pathol 1988, 37:351-362.

30. Wijesundera R, Bailey J, Byrde R, Fielding A: Cell wall degrading enzymes of Colletotrichum lindemuthianum: their role in the development of bean anthracnose. Physiol Mol Plant Pathol 1989, 34:403-413.

31. Knogge W: Fungal pathogenicity. Curr Opinion Plant Biol 1998, 1:324-328.

32. Dodds PN, Rafiqi M, Gan PHP, Hardham AR, Jones DA, Ellis JG: Effectors of biotrophic fungi and oomycetes: pathogenicity factors and triggers of host resistance. New Phytologist 2009, 183:993-1000.

33. Rodríguez-Guerra R, Acosta-Gallegos J, González-Chavira M, Simpson J: Patotipos de Colletotrichum lindemuthianum y su implicación en la generación de cultivares resistentes de frijol. Agricultura técnica en México 2006, 32:101-114.

34. Hernández-Silva L, Piñón-Escobedo C, Cano-Camacho H, Zavala-Páramo MG, Acosta-Rodríguez I, López-Romero E: Comparison of fungal growth and production of extracellular pectin lyase activity by pathogenic and nonpathogenic races of Colletotrichum lindemuthianum cultivated under different conditions. Physiol Mol Plant Pathol 2007, 70:88-95.

35. Tu J: An improved Mathur's medium for growth, sporulation, and germination of spores of Colletotrichum lindemuthianum. Microbios 1985 40:87-96.

36. Fry SC: Wall polymers: chemical characterization. The growing plant cell: chemical and metabolic analysis New Jersey: The Blackburn Press; 2000, 102-115.

37. Ausubel F, Brent R, Kingston R, Moore D, Seidman J, Smith J, Struhl K: Short Protocols in Molecular Biology. 4 edition. Wiley John \& Sons Inc; 1999, 1104

38. Borneman J, Hartin RJ: PCR Primers That Amplify Fungal rRNA Genes from Environmental Samples. App Env Microbiol 2000, 66:4356.

39. Grabe N: AliBaba2: context specific identification of transcription factor binding sites. In Silico Biol 2002, 2:1-15.

40. Matys V, Kel-Margoulis OV, Fricke E, Liebich I, Land S, Barre-Dirrie A, Reuter I, Chekmenev D, Krull M, Hornischer $K$, et al: TRANSFAC and its module TRANSCompel: transcriptional gene regulation in eukaryotes. Nucleic Acids Res 2006, 34:D108-D110.

41. Nielsen H, Engelbrecht J, Brunak S, Heijne von G: Identification of prokaryotic and eukaryotic signal peptides and prediction of their cleavage sites. Protein Eng 1997, 10:1-6.

42. Gasteiger E, Hoogland C, Gattiker A, Duvaud S, Wilkins MR, Appel RD, Bairoch A: Protein identification and analysis tools on the ExPASy server. In The Proteomic Protocols Handbook. Edited by: Walker JM, Totowa. NJ: Humana Press Inc; 2005:571-607.

43. Larkin MA, Blackshields G, Brown NP, Chenna R, McGettigan PA McWilliam H, Valentin F, Wallace IM, Wilm A, Lopez R, et al: Clustal W and Clustal $\times$ version 2.0. Bioinformatics 2007, 23:2947-2948.

44. Huelsenbeck JP, Ronquist F: MRBAYES: Bayesian inference of phylogenetic trees. Bioinformatics 2001, 17:754-755.

45. Philippe H, Delsuc F, Brinkmann H, Lartillot N: PHYLOGENOMICS. Annu Rev Ecol Evol Syst 2005, 36:541-562. 
46. Tamura K, Dudley J, Nei M, Kumar S: MEGA4: Molecular Evolutionary Genetics Analysis (MEGA) software version 4.0. Mol Biol Evol 2007, 24:1596-1599.

47. Saitou N, Nei M: The neighbor-joining method: a new method for reconstructing phylogenetic trees. Mol Biol Evol 1987, 4:406-425.

48. Arnold K, Bordoil L, Kopp J, Schwede T: The SWISS-MODEL workspace: a web-based environment for protein structure homology modelling. Bioinformatics 2005, 22:195-201.

49. Guex N, Peitsch MC: SWISS-MODEL and the Swiss-Pdb Viewer: An environment for comparative protein modeling. Electrophoresis 1997, 18:2714-2723.

50. Van Gunsteren WF, Billeter WF, Eising AA, Hunenberger $\mathrm{PH}$, Krüger $\mathrm{P}$, Mark AE: Biomolecular simulation: The GROMOS96 manual und user guide. vdf Hochs-chulverlag AG an der ETH Zurich and BIOMOS b v Zurich, Groninger; 1996

51. Birzele F, Gewehr JE, Csaba G, Zimmer R: Vorolign-fast structural alignment using Voronoi contacts. Bioinformatics 2007, 23:205-211.

52. Barthel D, Hirst JD, Błażewicz J, Burke EK, Krasnogor N: ProCKSI: a decision support system for Protein (Structure) Comparison, Knowledge, Similarity and Information. BMC Bioinformatics 2007, 8:416.

53. Sokal RR, Michener CD: A statistical method for evaluating systematic relationships. Univ Kans Sci Bull 1958, 38:1409-1438.

54. Kozak M: Point mutations define a sequence flanking the AUG initiator codon that modulates translation by eukaryotic ribosomes. Cell 1986, 44:283-292.

55. Kurtz S, Shore D: RAP1 protein activates and silences transcription of mating-type genes in yeast. Genes Dev 1991, 5:616-628.

56. Andrianopoulos A, Timberlake EE: The Aspergillus nidulans abaA gene encodes a transcriptional activator that acts as a genetic switch to control development. Mol Cell Biol 1994, 14:2503-2515.

57. Borneman AR, Hynes MJ, Andrianopoulos A: The abaA homologue of Penicillium marneffei participates in two developmental programmes: conidiation and dimorphic growth. Mol Microbiol 2000, 28:1034-1047.

58. Benoist C, O'Hare K, Breathnach R, Chambon P: The ovalbumin genesequence of putative control regions. Nucleic Acids Res 1980, 8:127-142.

59. Zaret KS, Sherman F: DNA sequence required for efficient transcription termination in yeast. Cell 1982, 28:563-573.

60. Nevalainen KM, Teo VSJ, Bergquist PL: Heterologous protein expression in filamentous fungi. Trends Biotechnol 2005, 23:468-474.

61. Jeoh T, Michener W, Himmel ME, Decker SR, Adney WS: Implications of cellobiohydrolase glycosylation for use in biomass conversion. Biotechnol Biofuels 2008, 1:1-10.

62. Bayer EA, Belaich J-P, Shoham Y, Lamed R: The cellulosomes: multienzyme machines for degradation of plant cell wall polysaccharides. Annu Rev Microbiol 2004, 58:521-554.

63. van Dyk JS, Sakka M, Sakka K, Pletschke BI: Identification of endoglucanases, xylanases, pectinases and mannanases in the multienzyme complex of Bacillus licheniformis SVD1. Enzym Microb Tech 2010, 47:112-118.

64. de Vries RP: Regulation of Aspergillus genes encoding plant cell wall polysaccharide-degrading enzymes; relevance for industrial production. Appl Microbiol Biotechnol 2003, 61:10-20

65. Martens-Uzunova ES, Schaap PJ: Assessment of the pectin degrading enzyme network of Aspergillus niger by functional genomics. Fungal Genet Biol 2009, 46:170-179.

66. Zhu J, Weng Z: FAST: A novel protein structure alignment algorithm. Proteins 2004, 58:618-627.

67. Yona $G$, Kedem $K$ : The URMS-RMS hybrid algorithm for fast and sensitive local protein structure alignment. J Comput Biol 2005, 12:12-32.

68. Acosta-Rodríguez I, Piñón-Escobedo C, Zavala-Páramo MG, López-Romero E, Cano-Camacho H: Degradation of cellulose by the bean-pathogenic fungus Colletotrichum lindemuthianum. Production of extracellular cellulolytic enzymes by cellulose induction. Antonie Van Leeuwenhoek 2005, 87:301-310.

69. Herbert C, Boudart G, Borel C, Jacquet C: Regulation and role of pectinases in phytopathogenic fungi. In Advances in pectin and pectinase research Edited by: Voragen F, Schols H, Visser Redited by Netherlands: Kluwer academic publishers 2003, 201-201208.

70. Have Ten A, Tenberge K, Benen J: The contribution of cell wall degrading enzymes to pathogenesis of fungal plant pathogens. In The Mycota XI
Edited by: KempkenF edited by Berlin, Germany: Springer Verlag 2002, 341-358.

71. Lagaert S, Belien T, Volckaert G: Plant cell walls: Protecting the barrier from degradation by microbial enzymes. Semin Cell Dev Biol 2009, 20:1064-1073.

72. Alghisi P, Favaron F: Pectin-degrading enzymes and plant-parasite interactions. Eur J Plant Pathol 1995, 101:365-375.

73. Maulik A, Ghosh H, Basu S: Comparative study of protein-protein interaction observed in Polygalacturonase-inhibiting proteins from Phaseolus vulgaris and Glycine max and Polygalacturonase from Fusarium moniliforme. BMC Genomics 2009, 10:S19.

74. King BC, Waxman KD, Nenni NV, Walker LP, Bergstrom GC, Gibson DM: Arsenal of plant cell wall degrading enzymes reflects host preference among plant pathogenic fungi. Biotechnol Biofuels 2011, 4:4.

75. Dodds PN: Genome Evolution in Plant Pathogens. Science 2010, 330:1486-1487.

76. Baxter L, Tripathy S, Ishaque N, Boot N, Cabral A, Kemen E, Thines M, AhFong A, Anderson R, Badejoko W, et al: Signatures of adaptation to obligate biotrophy in the Hyaloperonospora arabidopsidis genome. Science 2010, 330:1549-1551.

77. Huson D, Richter D, Rausch C, Dezulian T, Franz M, Rupp R: Dendroscope: An interactive viewer for large phylogenetic trees. BMC Bioinformatics 2007, 8:460.

doi:10.1186/1471-2180-11-260

Cite this article as: Lara-Márquez et al:: Cloning and characterization of a pectin lyase gene from Colletotrichum lindemuthianum and comparative phylogenetic/structural analyses with genes from phytopathogenic and saprophytic/opportunistic microorganisms. BMC Microbiology 2011 $11: 260$

\section{Submit your next manuscript to BioMed Central and take full advantage of:}

- Convenient online submission

- Thorough peer review

- No space constraints or color figure charges

- Immediate publication on acceptance

- Inclusion in PubMed, CAS, Scopus and Google Scholar

- Research which is freely available for redistribution

Submit your manuscript at www.biomedcentral.com/submit
C Biomed Central 